\title{
Feitiçaria: Terminologia e Apropriações
}

\author{
Surane Pinho Pêpe $e^{1}$
}

\begin{abstract}
Resumo: O presente artigo discute definições e conceitos de termos relativos ao tema feitiçaria e o contexto em que surgiram, assim como a relação entre as noções de feitiçaria e bruxaria. Parte da análise da série de ensaios de William Pietz, intitulada The Problem of the Fetish, publicados entre 1985 e 1988, Além de abordar a dificuldade de entendimento, por parte dos europeus, das práticas rituais africanas, analisa a apropriação do termo fetiche por autores ocidentais a partir do Iluminismo. O objetivo deste artigo é oferecer subsídios para a compreensão do tema com base em dados históricos, na análise de enfoques etnográficos, sociológicos e psicanalíticos, assim como evidenciar a lógica que norteia o pensamento da África Central e Ocidental, no que concerne às suas práticas religiosas, e a relação entre a lógica dessas práticas e as apropriações dos termos ora focalizados no contexto ocidental.
\end{abstract}

Palavras-chave: Conceitos; Feitiçaria; Bruxaria; África; Ocidente.

\begin{abstract}
This paper discuss the definitions and concepts of the terms related to witchcraft and the context in which they arose, as well as their relationship with the notions of socerer. Initially, it is analyzed the essays of William Pietz, entitled "The Problem of the Fetish", this work has been published between 1985 and 1988 and discuss the difficulties of the Europeans in apprehend the African religious practices. In the same oeuvre is examined the appropriations of the word fetish by authors who lived in the age of enlightenment in occidental countries. The objective of this article is provide subsidies on understanding the African witchcraft and ritual practices based on historical data, analysis of ethnographic, sociological and psychoanalytic approaches. On the other hand, its keeps the aiming of understand the logic behind the way of thinking of West and Central Africa people in terms of their religious practices and the relations between this logic approach and the appropriations of western terms on their primary vocabulary.
\end{abstract}

Keywords: Concepts; Witchcraft; Socerer; Africa; West.

\section{Introdução}

Dedicamos este trabalho aos aspectos terminológicos e conceituais relacionados ao tema feitiçaria e bruxaria, com o objetivo de traçar um quadro que permitisse a compreensão das circunstâncias históricas e ideológicas em que ocorre o uso desses termos, assim como a lógica que permeia o pensamento africano e o ocidental no campo da religião e em outros campos do conhecimento nos quais o termo aparece. Realizamos uma revisão bibliográfica, tomando como referência principal os ensaios de William Pietz. Também pesquisamos sobre o tema em textos de Evans-Pritchard, De Brosses, Frazer e Karl Marx, Robert Farris Thompson, Max Gluckmann, e Mary Douglas.

O estudo proposto foi estimulado pela necessidade de reunir dados que facilitassem posteriores reflexões sobre as práticas religiosas afro-brasileiras. Entretanto, sua relevância está no fato de que as práticas ditas de feitiçaria, bruxaria e magia estão presentes em diversas sociedades há muito tempo e se constituem, por sua vez, em parte integrante, ou mesmo central, segundo Parés (2006, p.104), do sistema religioso africano atual. Portanto, são focalizadas, neste trabalho, as informações relacionadas a conceitos e apropriações, sendo suas referências voltadas para o campo religioso na África.

Como observou Geschiere (2006, p. 9), a tradução do termo "feitiçaria" ("bruxaria", "magia" e "sorcellerie") é precária pelas implicações pejorativas que assumiu no

\footnotetext{
1 Professora Assistente da Universidade Federal do Recôncavo da Bahia. Mestre em Arqueologia e História
} da Arte pela Université Catholique de Louvain (Bélgica). 
Ocidente. Esse autor chegou a propor sua substituição por outras expressões, a exemplo de "força oculta" ou "tipo ideal de energia" (GESCHIERE, 2006, p. 9).

Ainda segundo Geschiere (2006, p. 12), só houve uma abertura com relação ao tema da feitiçaria na África nos últimos vinte anos, depois das primeiras décadas da independência das colônias européias nesse continente, as quais, na sua maioria, ficaram independentes entre as décadas de 1950 e 1970. Falar de feitiçaria chamava a atenção para algo que podia ser considerado "primitivo". Esse tabu diminuiu e passaram a chegar aos meios de comunicação oficiais - rádio, televisão e jornal - anúncios de terapias com curandeiros tradicionais. Entretanto, o acesso ao discurso da feitiçaria ainda é restrito a um número limitado de pessoas, o que está ligado à própria natureza do assunto e ao fato de que, historicamente e ainda no presente, a feitiçaria e a bruxaria são alvos de desconfianças, acusações e perseguições, deixando as pessoas num claro estado de vulnerabilidade.

\section{Termos e Conceitos}

São ditas religiões fetichistas aquelas que comportam o culto ao fetiche, palavra usada na língua francesa inicialmente, derivada do português "fetisso" / "feitiço", que quer dizer "coisa feita". No contexto das religiões, o feitiço implica a personificação de objetos materiais, a crença em um poder sobrenatural que atua para que determinada coisa aconteça, além de práticas determinadas. O feiticeiro é quem faz o feitiço, o manipulador de forças sobrenaturais. São diversas as formas sob as quais os fetiches aparecem, como veremos adiante.

Os termos fétiche e fétichisme, tal qual apareceram na língua francesa, marcaram teorias sociais pela apropriação por parte de diversas disciplinas, a partir do século XIX, como a etnografia, a história das religiões, a sociologia, a psicanálise e a psiquiatria clínica. Também foram utilizados por filósofos da estética modernista.

Ao tema fetiche e suas implicações conceituais, William Pietz dedicou vários ensaios que publicou nos anos 1980. Sobre a origem do termo como idéia e problema, e como objeto, Pietz (1987, p. 86) afirmou ter surgido nos séculos XVI e XVII, no espaço de cruzamento de culturas, na costa oeste da África, onde ocorria o tráfico de escravos. Nessa época, teria se desenvolvido a palavra portuguesa "fetisso" (feitiço), usada na Baixa Idade Média para designar "práticas mágicas" ou "bruxaria” (PIETZ, 1985, p. 5). Essas práticas não eram específicas da África Subsaariana, estavam também presentes entre mulçumanos e cristãos, e seu conhecimento contribuiu para que se interpretasse feitiçaria como idolatria. 
A bruxaria européia tornou-se poderosa na Idade Média. Dizia-se possuidora de segredos egípcios e de outros portados pelas sibilas romanas, donde parecem ter procedido “incontáveis processos terapêuticos e mágicos, especialmente amorosos, filtros, benzeduras, orações, e ensalmos" (CASCUDO, 1962, p. 309).

$\mathrm{Na}$ costa oeste africana, especialmente na Costa da Mina, onde o tráfico de escravos resistiu durante vários séculos, ocorreu o contato entre o cristianismo, as tradições das sociedades de linhagem e o sistema de mercado e capital, emergindo a problemática da possessão ou incorporação do objeto material (PIETZ, 1985, p. 6).

Em 1436, quando os portugueses chegaram à Guiné, encontraram uma organização social mais complexa do que imaginavam e cultos com concepções diferentes daquelas das religiões de revelação. O pensamento cristão fez com que enxergassem a prática da idolatria pelo povo africano (Pietz 1987, p. 34), porque as concepções conhecidas pelos cristãos eram as trazidas da tradição medieval: a idolatria e o pacto com o diabo ou demônio. Os portugueses não conseguiam compreender as práticas rituais no contexto africano e as confundiam com suas práticas cristãs de condenação à "bruxaria". Essa percepção pôde ser compreendida quando se procedeu ao estudo das leis. Segundo Pietz, no seu ensaio The Problem of Fetish, II: the origin of fetish (1987), diversas leis regulavam a bruxaria no mundo do cristianismo desde os séculos IV e $\mathrm{V}$, ainda no tempo dos primeiros reis cristãos. Leis formuladas entre a época de Costantino e a de Teodósio tinham como alvo práticas mágicas de superstição; várias delas eram divinatórias, condenadas como maleficium, e os crimes contra a religião eram tidos como sacrilégios, entre eles o envenenamento, o uso de ervas e de práticas mágicas que fizessem morrer ou que fossem afrodisíacas (PIETZ, 1987, pp. 31-32).

Outra fase de endurecimento das leis com a finalidade de perseguir a bruxaria ocorreu no século XII, marcado pelo fortalecimento da Igreja Católica como instituição. O termo latino facticius, que é, provavelmente, a raiz primeira da palavra feitiço, foi encontrado por Pietz (1987, p. 33) no Código Municipal para Tervel, em Aragão, no Fórum Turolij, que data do século XII. O foco dessas leis eram as mulheres que fizessem ligadura de trompas. Condenavam também pessoas que usassem ervas e medicamentos, assim como materiais que produzissem efeitos capazes de modificar o estado físico do indivíduo (PIETZ, 1987, pp. 33-34).

No português medieval, facturae apareceu como sinônimo de malefício e sortilégio, e faiturier, como de bruxa ou feiticeira (DU CAGNE, 1938 apud PIETZ, 1987, p. 34). Na lei de Castilha (1260), aparecem os termos fechura, significando a feitura do objeto, fechizo como 
o objeto e fechiceiro, para denominar quem fabrica o objeto. Essas palavras, em espanhol moderno, são iniciadas com $b$ no lugar de $f$. Em português do século XIV, "bruxaria" significava o mesmo que "feitiçaria", havendo o "feitiço", ou seja, o objeto da feitiçaria, e o "feiticero". No tempo do Papa Paulo XXII, essas palavras se afirmam tanto no espanhol quanto no português como resultado da política de perseguição a bruxos, àquela altura, sinônimo de feiticeiros. Em francês, firmou-se o termo sorcerer, em inglês, witchcraft, e, em alemão, hexerie.

Nos séculos XIV e XV, promulgaram-se leis contra a feitiçaria como a lei de 1403, chamada Dos Feiticeiros, absorvida depois pelo Código de Afonso V (PIETZ, 1987, p. 34). O historiador Trevor-Roper (1996 apud DOUGLAS, 1991, p. 61), atento às questões sociológicas, chamou a atenção para o que ele considerou um paradoxo: o fato de a crença em bruxas ter sido reforçada, de forma apaixonada, por homens cultos do final do século XVI. Na opinião de Mary Douglas (1991, p. 63), que editou o livro Witchcraft, confessions and accusations (1970), esse paradoxo é relativo, tendo em vista que, no Renascimento, se buscou como referência a Antiguidade, e nela já se copiavam técnicas de feitiçaria e antifeitiçaria e se acusavam pessoas rivais de ser provocadoras do insucesso do outro.

Retomando a questão da terminologia, houve, de fato, uma mistura dos termos feitiçaria e bruxaria que revela a incompreensão por parte do europeu em relação à essência das práticas de feitiçaria que ocorriam na África. Conforme as observações de Pietz (1988), durante a primeira metade do século XVII, o termo "fetisso" estava presente em locais que faziam parte de rotas comerciais por onde passavam comerciantes norte-europeus. Estes, especialmente os protestantes, costumavam fazer confusão entre cristianismo, islamismo, judaísmo e paganismo, o que contribuiu para dificultar o entendimento das concepções de "feitiçaria" nas culturas africanas. A palavra "fetisso" era usada, naquela época, pela população afro-portuguesa do Senegal, nas leis islâmicas de cidades à altura do Rio Gâmbia, no reino Mande de Serra Leoa, pelas populações africanas que tinham contato com europeus na Costa do Ouro e na Costa dos Escravos (PIETZ, 1988, p. 108).

$\mathrm{Na}$ África, os termos "feitiçaria" e "bruxaria", "feiticeiro" e "bruxo" também aparecem com significados distintos, e encontram correspondência nas línguas africanas. $O$ exemplo mais conhecido é o da sociedade dos azande, no Sudão, estudada por Edward Evan Evans-Pritchard (1902-1973) nos últimos anos da década de 1920. O autor revelou os resultados de sua pesquisa no livro Witchcraft, oracles and magic among the Azande (1937), cuja tradução foi publicada no Brasil em 1978. Nesse trabalho, que teve maior repercussão cerca 
de trinta anos depois de escrito (DOUGLAS, 1991, p. 32), Evans-Pritchard analisou a bruxaria, com base no método que chamamos hoje de pesquisa participante.

Evans-Pritchard enfatizou que a bruxaria entre os azande é uma forma de explicar os infortúnios, e de regular a conduta humana e as relações sociais. Para os azande, a bruxaria (mangu) e a feitiçaria são distintas. Bruxaria é "uma substância existente no corpo dos bruxos" (EVANS-PRITCHARD, 1978, p. 33). Diferentemente da feitiçaria, manipulação de objetos com finalidade causal, que faz um indivíduo adoecer e morrer num espaço de tempo curto, a bruxaria se dá num processo lento. Trata-se de uma percepção comum a diversos povos da África Central e Ocidental, que pensam na bruxaria como sendo um fenômeno orgânico e hereditário.

Os Azande acreditam que certas pessoas são bruxas e podem lhes fazer mal em virtude de uma qualidade intrínseca. Um bruxo não pratica ritos, nem faz feitiçaria. Um ato de bruxaria é um ato psíquico. Eles crêem ainda que os feiticeiros podem fazê-los adoecer por meio da execução de ritos mágicos que envolvem drogas maléficas (EVANSPRITCHARD, 1978, p. 33).

O bruxo, segundo depoentes de Evans-Pritchard, possui:

[...] uma pequena bolsa ou inchação enegrecida, ou avermelhada, de forma oval dentro da qual costumam ser encontrados pequenos objetos ou sementes de abóbora, gergelim, etc. Essa sustância se encontra 'presa à beira do fígado' e, ao abrir a barriga, 'basta furá-la que ela explode"” (EVANS-PRITCHARD, 1978, p. 34).

Os azande crêem que a bruxaria é transmitida por descendência unilinear. O genitor bruxo transmite a seus filhos homens essa característica física e a genitora bruxa transmite apenas às filhas a mesma característica (EVANS-PRITCHARD, 1978, p. 34). O autor apontou diversas contradições nesse sistema e afirmou que, apesar de os azande compreenderem argumentos lógicos, posicionam-se contrários a eles. Como exemplo, acredita-se que a bruxaria é hereditária, todo o clã seria bruxo, mas consideram bruxos apenas os parentes mais próximos do bruxo conhecido. Ou, se ficar provado que uma pessoa é bruxa, seus parentes próximos ficam com medo de ser considerados bruxos e o acusam de bastardo. Ainda, se um filho de bruxo não utilizar sua substância-bruxaria ao longo de sua vida, não pode ser considerado um bruxo (EVANS-PRITCHARD, 1978, p. 36). Crêem que a bruxaria aumenta e torna-se mais potente com a idade, pois pensam que a substância-bruxaria cresce com o tempo, por isso têm medo dos idosos (EVANSPRITCHARD, 1978, p. 39). 
$\mathrm{Na}$ visão de Evans-Pritchard, a bruxaria serve de explicação para todos os infortúnios da vida; mesmo que as causas possam parecer as mais lógicas, encontram uma explicação direta ou indireta na bruxaria.

Da forma como os Azande concebem os bruxos, eles não podem existir, mas o conceito de bruxaria lhes fornece uma filosofia para explicar as relações entre os homens e o infortúnio; para explicar de forma breve eventos funestos, assim como é "um sistema de valores que regula a conduta humana” (EVANS-PRITCHARD, 1978, p. 49).

Para saber se alguém está "embruxado", consultam o oráculo do veneno. Bruxos confirmados são aqueles denunciados pelo oráculo muitas vezes. A morte é, por sua vez, compreendida como resultado de bruxaria e deve ser vingada, assim como as demais práticas ligadas à bruxaria devem ser vingadas. Tudo indica que não há rancor por parte da família do bruxo, pois, quando uma pessoa mata por bruxaria, o crime é de sua exclusiva responsabilidade (EVANS-PRITCHARD, 1978, p. 37).

$\mathrm{Na}$ interpretação de Evans-Pritchard (1978, p. 55), a bruxaria, na crença azande, não contradiz o princípio de causa e efeito dos fenômenos naturais. Para o autor, os azande percebem que a bruxaria não é a única causa dos fenômenos que provocam seus infortúnios, e certas ações não são possíveis de ser justificadas como bruxaria, tal qual o adultério ou a traição ao príncipe, porque a bruxaria não faz com que o indivíduo cometa esses crimes. Na lógica azande, a bruxaria está na própria pessoa (EVANS-PRITCHARD, 1978, p. 56).

A punição para quem assassina um membro do grupo é ser executado. Se for um membro de outra "tribo" quem matou seus parentes ou seu príncipe, serão tomadas medidas para descobrir o bruxo responsável. Além do mais, é traição afirmar que alguém foi morto por bruxaria por ordem do rei. Isso se constitui numa ofensa à autoridade real. No caso de alguém consultar o oráculo para saber quem é o bruxo responsável pela morte de um parente executado por ordem do rei, esta pessoa será executada (EVANSPRITCHARD, 1978, p. 46). Trata-se da imunidade daquele que possui o poder político, logo, de sua preservação no contexto social. Segundo o autor, em certa medida, nobres e plebeus poderosos estão imunes a acusações de bruxaria (EVANS-PRITCHARD, 1978, p. 41).

Quanto à quebra de certos tabus, esta é também causa atribuída ao infortúnio. É o caso de uma pessoa que praticou incesto e contraiu lepra, atribui-se ao incesto a causa da lepra, o que sugere a noção de causa e efeito como forma de controle social. 
Para Evans-Pritchard (1978, p. 58), quem sofre o infortúnio e os mais próximos, o atribuem à bruxaria, mas provavelmente as outras pessoas não o fazem; como exemplo, um homem muito idoso, cujos parentes atribuem a causa de sua morte à bruxaria, porém os outros compreendem que é a própria velhice, a causa.

Nos anos 1970, o antropólogo Max Gluckman (1991) escreveu sobre a lógica da ciência e da bruxaria africana, utilizando como referencial o texto de Evans-Pritchard sobre os azande. Segundo Gluckman (1991, p. 7), embora as investigações tenham sido realizadas entre os azande no Sudão, os argumentos de Evans-Pritchard podem ser estendidos a outras "tribos africanas", como chamou o autor, que "acreditam em bruxaria, oráculos, adivinhação e magia". Em sua publicação, Gluckman questionou sobre as distinções entre as lógicas africana e européia, partindo do consenso da opinião científica, que não aponta grandes diferenças entre os cérebros do homem africano e do europeu e defende que, se existem, não são suficientes para explicar as diferenças entre suas culturas e seus modos de pensar. Salientou a importância de conhecer a história das "tribos", melhor dizendo, das sociedades, e seu contato com outros povos, além de outros fatores que têm de ser levados em conta a fim de se compreender essas diferenças entre a visão européia ocidental e a da África Subsaariana.

De acordo com Gluckman (1991, p. 10), os africanos possuem conhecimentos técnicos precisos e científicos. Suas leis e seus procedimentos são diferentes daqueles encontrados entre os europeus, mas, no âmbito do seu sistema, raciocinam com clareza e distinguem as questões. Conforme esse autor (1991, p. 13), o africano nasceu numa sociedade em que se acredita na bruxaria e, por essa razão, a estrutura mesma de seu pensamento, desde a infância, compõe-se de idéias mágicas e místicas. Além deste argumento que utiliza para diferenciar a lógica africana da européia, Gluckman (1991, p. 13) ressalta a importância de ser a bruxaria coisa vivida, muito mais do que raciocinada, acrescentando, ainda, que todas as ações cotidianas dos africanos estão relacionadas a ela, portanto, é preciso enfrentá-la.

\section{Apropriações do Termo Fetiche por Intelectuais Europeus}

Muitos textos de viajantes norte-europeus, disseminados na Europa no século XVII, foram, posteriormente, lidos por intelectuais do Iluminismo, como Hume, Voltaire, De Brosses e Kant. Mais adiante, no século XIX, Marx e Freud associaram ao termo fetiche sentidos diferentes do religioso, empregando-o em outros contextos. 
O Iluminismo introduziu uma visão racionalista, que negava maus espíritos, bruxos e magos. A elite intelectual passou a ter uma atitude científica quanto a esta questão, combinada à tendência mecanicista que emergia e à ideologia materialista cética (PIETZ, 1987, p. 36). Sob essas óticas, o fetiche como objeto de fabricação humana jamais poderia ter um poder sobrenatural.

De Brosses (1760, p. 10), em seu livro Du culte des dieux fétiches on paralèle de l'antique religion de l'Egypte avec la religion actuelle de nigritie, pediu permissão para inserir o termo "fétichisme" a fim de se referir aos cultos da Nigéria que empregam objetos materiais, mas também a outras situações em que os objetos de culto são animais, ou seres inanimados divinizados. O termo foi aplicado para defender uma teoria de religião primitiva já imbuída de princípios evolucionistas. Esse autor estava ligado ao círculo de Georges Louis Leclerc, conde de Buffon, cujas idéias influenciaram Jean-Baptiste de Lamarck e Charles Darwin um pouco mais tarde.

De Brosses criou a teoria da existência de três estágios evolutivos: fetichismo politeísmo - monoteísmo. Apresentou a idéia de que os primeiros cultos foram aos astros, e aos objetos terrestres materiais chamados "fetiches entre os negros africanos" (DE BROSSES, 1760, p. 10). Explicou de onde vem o termo fetiche:

Os negros da costa ocidental da África, e mesmo os do interior até à Núbia, território que faz limite com o Egito, adoram certas divindades que os europeus chamam "fetiches", termo usado pelos comerciantes do Senegal, derivado de "feitiço", que quer dizer coisa feita, encantamento, divino ou que se rende dos oráculos. Este termo, de raiz latina, vem de fatum, fanum, fari (DE BROSSES, 1760, p. 18-19). ${ }^{2}$

A percepção de De Brosses sobre o que chamou de "fétichisme" era de que este nasce com os "povos selvagens mergulhados na ignorância e na barbárie", provindos das "mais antigas nações do mundo", espalhadas por toda a Terra e mantidas, sobretudo, na África (DE BROSSES, 1760, pp. 14-15). Para o autor, esses “dois tipos de religião”, ou seja, aquelas em que se cultuam os astros e aquelas em que se cultuam objetos, são fontes que estão na base da mitologia oriental e grega, além de serem mais antigas que "a idolatria propriamente dita" (DE BROSSES, 1760, p. 11). Escreveu sobre seu espanto em relação ao gênero humano, que teria recebido de Deus instruções conforme a inteligência, mas teria caído num estado de estupidez bruta, o qual poderia ser visto como uma punição (DE BROSSES, 1760, p. 15). Na visão de De Brosses, tanto entre os negros africanos como entre a maioria dos "selvagens", não havia o conhecimento de deificação de homens.

\footnotetext{
2 Tradução nossa de trecho de fac-símile em versão digital, na língua francesa.
} 
Referindo-se à África do século XVIII, De Brosses (1760, p. 22) informou que cada localidade tinha a proteção de um fetiche. O guardião da habitação tinha seu altar elevado em praça pública. Aquele que o danificasse ou o destruísse seria punido. O infortúnio daquele que não tivesse sucesso seria atribuído a um "justo ressentimento" do seu fetiche (DE BROSSES, 1760, p. 24).

De Brosses (1760, p. 22) considerou fetichista o culto a uma árvore, uma montanha, um pedaço de madeira, um rabo de leão, uma pedra, uma concha, um peixe, uma vaca, um carneiro, ao mar, etc. Pietz $(1987$, p. 8) chamou a atenção para a "teoria do primeiro encontro", discurso comum nos textos que vão do século XV ao século XIX. Trata-se de adorar o que se vê à primeira vista, seja um animal, um pedaço de madeira, uma pedra ou um objeto qualquer. Essa prática não era específica das religiões africanas, ela também era comum entre mulçumanos e cristãos.

Um outro conceito desenvolvido com base na visão evolucionista é o de magia. Se, por um lado, De Brosses elaborou o esquema feitiçaria - politeísmo - monoteísmo, por outro, James Frazer, quase um século depois, apresentou o esquema focado na magia religião - ciência, objeto de seu livro The golden bough: a study in magic and religion ${ }^{3}$, publicado em 1890.

Segundo Frazer, o mago conhece da magia seu aspecto prático, sem analisar os processos mentais que baseiam suas práticas, tampouco refletir sobre os princípios abstratos intrínsecos à suas ações. Para o mago, a magia é uma arte, jamais uma ciência, pois o "verdadeiro conceito de ciência está ausente de sua mente rudimentar". (FRAZER, 1956, p. 34) ${ }^{4}$. Logo, a magia, para Frazer, era coisa de povos ditos inferiores. Todavia, ele estabeleceu uma analogia entre magia e ciência como "técnica".

Também foi Frazer que classificou a magia em: "magia simpática" e "magia contagiosa". Na primeira forma, domina o "princípio da semelhança”, ou da similitude dos fatos nas suas representações. Por basear-se na imitação, ela tem outras denominações como "magia imitativa ou homeopática" (FRAZER, 1956, pp. 33-34). Um exemplo de magia homeopática é acreditar que, destruindo a fotografia de um inimigo, destrói-se o inimigo (FRAZER, 1956, p. 36). Na magia contagiosa, domina a "lei do contato ou contágio”. Pressupõe que duas coisas que estiveram em contato atuam uma sobre a outra à distância (FRAZER, 1956, pp. 33-34). Neste caso, acredita-se que uma pessoa pode sofrer

\footnotetext{
3 O título da obra inspira-se numa pintura de William Turner, que mostra uma cena banhada de dourado, representando uma visão de sonho do lago de Nemi, chamado pelos antigos de "espelho de Diana", situado próximo a um bosque sagrado e ao santuário de Diana (FRAZER, 1956, p. 25).

${ }_{4}^{4}$ Os trechos entre aspas foram por nós traduzidos para o português, da versão espanhola do livro de Frazer, La rama dorada: magia y religion, publicada em 1956.
} 
algum dano se uma roupa ou objeto que lhe pertence for utilizado para alguma prática que tenha como objetivo prejudicá-la ou destruí-la.

Segundo Frazer (1956, p. 75), como detentor de poderes sobrenaturais, o mago não duvida de que as mesmas causas produzem sempre os mesmos efeitos, nem duvida do resultado das cerimônias, a menos que seus encantamentos sejam desbaratados ou contestados por outro "feiticeiro" mais forte. Nesse momento, o autor utilizou a palavra feiticeiro como sinônimo de mago.

Ainda no século XIX, Karl Marx dedicou algumas páginas de O Capital ao tema $O$ fetichismo da mercadoria: seu segredo. Para Marx (2006), a mercadoria aparenta ser uma coisa trivial e compreensível, como valor-de-uso, todavia, a transformação dos materiais em mercadorias pela atividade humana requer atividade cerebral dos nervos, músculos, sentidos, entre outras, duração do dispêndio ou quantidade de trabalho (MARX, 2006, p. 94).

A mercadoria é misteriosa para Marx:

[...] simplesmente por encobrir as características sociais do próprio trabalho dos homens, apresentando-as como características materiais e propriedades sociais inerentes aos produtos de trabalho, por ocultar, portanto, a relação social entre os trabalhos individuais dos produtores e o trabalho total, ao refleti-la como relação social existente, à margem deles, entre os produtos do seu próprio trabalho. (MARX, 2006, p. 94).

Enfatiza Marx que, através "[...] dessa dissimulação, os produtos do trabalho se tornam mercadorias, coisas sociais, com propriedades perceptiveis e imperceptiveis aos sentidos". O valor da mercadoria, para o autor, é fruto da organização social, que produz, consome e, a depender dos valores sociais, valoriza a mercadoria (MARX, 2006, p. 94). Considera a produção burguesa como a forma de mercadoria mais geral e mais elementar e, ainda, a que melhor ilustra os atributos fetichistas (MARX, 2006, p. 104).

Nos anos 1960, com o desenvolvimento tecnológico, apareceu a noção de que a mercadoria ganha uma "alma", com o aumento do consumo pela "sociedade da abundância do pós-guerra", da concorrência, da globalização, da publicidade, que encontrou, na ilusão pela imagem, formas de idealizar produtos. $\mathrm{Na}$ sociedade pósmoderna, retomou-se a idéia de fetichismo no sentido marxista, ou seja, de ilusão, mas para tratar do poder da imagem exercido sobre os consumidores. Nessa perspectiva, Fontenelle (2005, pp. 75-76) considerou estar havendo um "recrudescimento do fetichismo" e deu a este a denominação de "fetichismo das imagens", a fim de facilitar o entendimento da realidade atual. É a imagem que "passa a ser compreendida como fonte de desejo de valor", 
chegando a existir formas de consumo que o indivíduo sabe que são ilusórias, entretanto comporta-se como se não o soubesse (FONTENELLE, 2005, p. 79).

Outra apropriação do termo fétichisme ocorreu com Freud, que lhe deu uma outra conotação, de acordo com as teorias que defendia. Sua perspectiva enquadra-se na psicanálise e na psiquiatria clínica. No primeiro ensaio (1981, pp. 1172-1194) dos Tres ensayos para una teoria sexual, publicado pela primeira vez em 1905, Sigmund Freud considerou aberrações sexuais: desvios relativos ao objeto sexual (homossexualismo, pedofilia e zoofilia); e desvios relativos à finalidade sexual (transgressões anatômicas do objeto sexual; a fixação nas finalidades sexuais preliminares). Entre as transgressões anatômicas, ressaltou a "substituição inapropriada do objeto sexual" a que chamou de “fetichismo" (FREUD, 1981, p. 1182).

O substitutivo do objeto sexual é, em geral, uma parte do corpo muito pouco apropriada para fins sexuais (o pé e o cabelo) ou um objeto inanimado que está em visível relação com a "persona sexual", e especialmente com a sexualidade da mesma (prendas de vestir, roupa branca) (FREUD, 1981, p. 1183). ${ }^{5}$

Por que Freud se apropriou do termo "fetiche" para denominar esse tipo de transgressão? Segundo ele próprio: "este substitutivo se compara, não sem razão, com o fetiche no qual o selvagem encarna seus deuses" (FREUD, 1981, p. 1183). Podemos interpretar sua metáfora, dizendo que objetos sexuais "não apropriados", como certas partes do corpo ou objetos inanimados, ganham o interesse das pessoas transgressoras, assim como os fetiches usados nas religiões, ambos adquirem vida na medida em que lhe são atribuídos poderes.

Se, por um lado, a visão de Freud avançou em muitos pontos, constituindo-se a psicanálise em uma linha divisória, antes da psicanálise e depois da psicanálise; por outro, suas referências à selvageria e ao primitivismo comungavam com a visão evolucionista que predominava ainda à sua época e que influenciou seus estudos. Um exemplo disso é a obra Totem e tabu: algumas concordâncias entre a vida mental dos selvagens e dos neuróticos (1915), na qual Freud "procura demonstrar o paralelo evolucionista entre neurose e o funcionamento psíquico dos primitivos" (DALGALARRONDO, 1995, p. 41). Não apenas Freud, também Jung, Róheim e outros psicanalistas permaneceram fortemente influenciados por visões eurocêntricas, evolucionistas e paralelistas.

\footnotetext{
5 Tradução nossa de versão em espanhol.
} 
Dois pensadores voltados para o estudo da indústria cultural na pós-modernidade, Theodor Adorno e Max Horkheimer (1977 apud FONTENELLE, pp. 79-80), fizeram um paralelo entre a visão de Freud e a de Marx, e propuseram a idéia de que se estaria vivendo uma "perversão da cultura", provocada por uma forma social fetichista. Estenderam suas análises para a realidade histórica americana no contexto da indústria cultural, em que tudo se torna negócio. A denúncia de uma total "fetichização da cultura" contribuiu para a teoria crítica da sociedade contemporânea, baseada na exacerbação das relações de produção e consumo, na descartabilidade, desterritorialização e descontinuidade temporal.

Outra apropriação do termo "fetiche" se deu no campo da estética, por Michel Leiris (apud PIETZ, 1985, p. 11), ao escrever, em 1929, sobre a escultura de Giacometti. Nos anos 1920, Leiris freqüentava o meio artístico dos surrealistas, porém, no final dessa década, aproximou-se da antropologia, trabalhando com Marcel Griaule na redação de uma revista de arte e etnografia, intitulada Documents, dirigida por Bataille. Também escreveu $A$

África Fantasma, que é um relato, em estilo literário e autobiográfico, de uma missão etnográfica a Dacar-Djitubi, da qual participou.

Para o escritor Leiris (apud PIETZ, 1985, p. 11), o fetiche, como nos tempos antigos, está na base da existência humana. Segundo seu pensamento, na arte há quadros e esculturas capazes de atender às exigências de um fetichismo que ele considera sinônimo de amor próprio, o qual se projeta de dentro para fora e é capaz de levar o artista a exteriorizar seu mundo. Obras de arte são tidas pelo escritor como verdadeiros fetiches.

\section{O Fetiche e sua Irredutibilidade à Materialidade}

Pietz (1988, p. 109) mostrou que relatos do século XVII e XVIII se referem a descobertas de europeus, na Guiné, de seis tipos distintos de objetos associados ao conceito de "fetiche": objetos religiosos de sacramento (cruz e rosário); objetos estéticos e eróticos; objetos de valor econômico; talismãs quase-medicinais (amuletos de saúde, sorte e salvação); objetos de juramento; e objetos utilitários europeus.

Robert Thompson estudou a influência das tradições religiosas e visuais das regiões do Congo e de Angola sobre as Américas, no texto The two sign of four moments of the sun: Kongo art and religion in the Americas (1984). Reportou-se à lógica do pensamento religioso do Congo e à disseminação do uso de objetos de proteção, que ganharam corpo além do Atlântico, com a migração forçada de africanos para o Novo Mundo. O autor não utilizou termos como "fetiche" ou "feitiço"; ele buscou fazer uso de expressões no idioma bakongo, e, esporadicamente, referiu-se a feitiçaria ou bruxaria em seu texto. 
Thompson analisou os princípios do pensamento religioso dos bakongo, para quem a vida é cíclica e a morte faz parte de um processo de mudança. Associam o nascer do sol à vida e o pôr do sol, à morte. Quanto aos símbolos, a vida é representada pela luz do sol refletindo sobre o mundo, e a morte, pelo desenho espiral de uma concha de “kodya”. (THOMPSON, 1984, p. 106). A representação do cosmo - Tenda Nzáa Kongo - foi descrita por Wyatt MacGaffey (apud THOMPSON, 1984, p. 8). Trata-se do desenho que é feito no espaço ritual, em que aparece uma cruz grega centralizada. Suas linhas simbolizam: uma, o limite, e a outra, a ambivalência. A linha vertical liga a parte superior à inferior, que são interpretadas, na concepção bakongo, respectivamente, como Deus e o homem, ou a vida e a morte, ou Deus e a morte.

Numa versão da cruz yowa, mostrada por Thompson, ficou provada a idéia de circularidade, indicada por setas que circundam a cruz central, cujas terminações possuem, cada uma, um disco, que são os quatro momentos do sol, o que provavelmente sugeriu a Thompson o título do capítulo The sign of the four moments of the sun. Não há relação alguma com a crucificação do cristianismo, mas com a idéia de continuidade da vida. Esta idéia é também representada por uma linha oval no centro da representação, que indica a reencarnação. “Nenhum bakongo será destruído, ele voltarâ" (THOMPSON, 1984, p. 9).

Charmes (amuletos), comumente chamados e gris-gris, são constantemente produzidos pela sociedade bakongo. Seu panteão de divindades não é tão rico quanto o iorubano, no entanto, distinguiram-se pela forte tradição no uso de medicamentos sagrados, minkisi, dados por Deus à humanidade, segundo as crenças bakongo (THOMPSON, 1984, p. 106).

São fortemente especializados aqueles que lidam com poderes sobrenaturais, conforme a enumeração de especialidades feita por Thompson. Existe o rei, cujos papéis são: ser especialista ritual que zela pelo bem comum, e executar criminosos e inimigos do Estado. Tem outros especialistas em rituais (nganga): o que lida com amuletos (baganga nkisi); o que labuta com ervas e raízes (baganga mbuki); o que lida com adivinhação (baganga ngombo); e o que trabalha com espíritos misteriosos (baganga bisimbi). Há aquelas pessoas que são escolhidas durante a iniciação; elas compõem a sociedade de Lemba, criada em 1660. Há, também, a figura do feiticeiro (ndoki), desprovido de consciência social. Thompson ressaltou, ainda, que as influências do cristianismo permaneceram presentes no Congo, nas figuras do diabo e do bruxo (THOMPSON, 1984, p. 107).

O nkisi foi definido, em cerca de 1900, por Nsemi Isaki (apud THOMPSON, 1984, p.117), de origem Mu-Kongo, como um amuleto não só para proteger as pessoas doentes, 
mas também para afastar doenças. Pensava que os amuletos podiam ajudar as pessoas por eles terem vida própria e eterna. Os minkisi podem ser de folhas, conchas, cascas, pacotes, sacos, bolsas, vasilhas de cerâmica, imagens de madeira, estatuetas, trouxas de roupa etc. Cada nkisi contém substâncias medicinais (bilongo) e lhe é atribuída uma alma (mooyo).

Um tipo famoso de nkisi é feito com uma sacola de ráfia amarrada com uma corda, onde são colocados muitos objetos e medicamentos embebidos em caolim, e no fundo peças de cristal e de pedra, que lembram a configuração do cosmograma bakongo (THOMPSON, 1984, p. 118).

Nas Américas, a feitura de cosmogramas para rituais de iniciação, a preparação de remédios sagrados, o uso de amuletos, inclusive em túmulos, a proteção ancestral, o uso de objetos pendurados em árvores e de raízes a fim de proteger os moradores de um lugar são tradições derivadas do Congo e de Angola.

Em seu ensaio The problem of fetish, I (1987, p. 7), Pietz apontou algumas características que considera essenciais ao fetiche: a irredutibilidade à materialidade; a singularidade e a repetição. $O$ fetiche é irredutível à materialidade; sua essência está numa espécie de possessão material. Esta característica ficou mais do que clara nas informações fornecidas anteriormente, ao citar exemplos de nkisi.

Outra diferença fundamental é a existente entre a concepção de fetiche e a de ídolo, desenvolvida no português medieval. No ídolo, há uma relação de semelhança icônica entre objeto material e modelos imateriais. A idolatria, na Europa medieval, era entendida como princípio da fé cristã. (PIETZ, 1985, p. 7). Tanto o tema idolatria quanto feitiçaria são importantes como objetos de pesquisa.

O fetiche envolve também singularidade e repetição. Para MacGaffey (apud PIETZ, 1985, p. 7), é uma fabricação composta, sendo os componentes que o identificam não apenas material, mas também desejos, crenças e estruturas narrativas. Acredita-se que o fetiche tem o poder de repetir atos, forjando relações, e, assim, articular as coisas de outra maneira (PIETZ, 1985, p. 15).

Em The problem of fetish, II (1987, p. 23), Pietz afirmou que, apesar das apropriações do termo fetiche pela etnografia, história das religiões, marxismo e positivismo sociológico, existem aspectos comuns nos discursos dessas áreas. Além de ter citado a materialidade, lócus da atividade religiosa ou de um investimento psíquico, e a capacidade de repetir um processo singular de fixação, aborda mais dois pontos: a dependência do fetiche nas relações sociais; e, por último, a relação do objeto fetiche com o corpo do indivíduo, o que 
explicou como sendo uma espécie de controle externo, dirigido por poderes externos a uma pessoa, o qual é capaz de afeta-la.

Uma das confusões dos europeus em relação às crenças dos africanos estava na convicção de que estes faziam distinção entre objetos religiosos e objetos com finalidades decorativas, ornamentos. Nesse caso, o fetiche teria dupla função. Essa idéia está presente tanto em Atkins (1737), quanto em Villault (1667) (PIETZ, 1988, p. 110). O comerciante holandês Willem Bosman, que, em 1703, escreveu sobre fetiches africanos e sobre o culto à serpente no porto de Ouidah, foi o primeiro a tratar da não intenção estética dos fetiches africanos, tendo em vista seus propósitos: superstição e interesse (PIETZ, 1988, p. 105). Fetiches de ouro impressionavam esses viajantes, tornando-se objeto de desejo pelo interesse econômico por parte dos europeus, o que fez chegar, nos países ocidentais, máscaras, objetos, esculturas e outras peças das sociedades tradicionais africanas, que foram considerados como obras de arte.

\section{Considerações Finais}

A compreensão do tema proposto foi facilitada pelo fato de terem os ensaios de William Pietz e o artigo de Thompon nos servido como ponto de partida, trazendo um olhar ponderado entre a história e a antropologia. Outro aspecto importante foi a tentativa - acreditamos que bem-sucedida - de eliminar qualquer sorte de preconceito em relação ao tema feitiçaria e bruxaria, cuja lógica foge a explicações racionalistas.

Percebemos que a leitura dos três ensaios de Pietz não pode ser feita de forma isolada; trata-se de um conjunto de idéias que se complementam e, às vezes, se repetem, por serem fruto de um aprofundamento de suas pesquisas. Já a consulta dos textos originais de De Brosses, Marx e Freud ajudaram na construção de nossa análise.

O termo "fetiche" originou-se, provavelmente, na costa oeste da África entre os séculos XVI e XVII, durante a confluência de ideologias cristãs, mercantilistas e das sociedades locais. Os estudos de Pietz levaram-no a crer que esta palavra procede da palavra latina "facticius" (século XII), que deu origem ao termo em português medieval "facturae" (usado no sentido de malefício ou sortilégio); do qual derivou a palavra "fetisso", "feitiço" (coisa feita), aparecendo "fétiche", na língua francesa, e depois o termo "fetiche", na língua portuguesa.

O europeu não conseguiu apreender a essência da feitiçaria praticada em território africano e a confundiu com a bruxaria, que se desenvolvera na Europa. Ainda no português medieval, "faiturier" era o termo usado no sentido de bruxa ou feiticeira. A mistura dos termos deveu-se ao fato de que os europeus pensaram tendo como referência as práticas 
ocidentais de idolatria e da crença no diabo. Outro engano foi terem achado que os africanos faziam distinção entre objetos religiosos e objetos decorativos. A difusão na Europa dessa idéia de fetiche por viajantes norte-europeus serviu de base ao pensamento iluminista do século XVIII, racional, cético e anti-fetichista. Nessa época, começaram a se desenvolver teorias evolucionistas que tentavam explicar as religiões, tendo sido a de De Brosses aquela que se utilizou do termo "fétichisme" para designar um primeiro estágio, no qual ocorria o culto a um objeto animado ou inanimado; seguido do monoteísmo; e, depois, do politeísmo. Após quase um século, James Frazer elaborou uma explicação evolucionista que incluía: magia (por imitação ou por contágio), religião e ciência. Nenhuma dessas idéias explorava a completa essência do feitiço, apesar de abordarem alguns aspectos relacionados a este.

Entre posteriores apropriações dos termos "fétiche" e "fétichisme" por Marx, Freud e Leiris, o fetiche exercia magnetismo ou atração, e sedução. Marx enfatizou o caráter misterioso da mercadoria devido à intervenção da atividade humana na produção dos objetos de consumo. O conceito de Marx exerceu influência sobre a visão que circula na atualidade de fetichismo da imagem publicitária, além do exercido pelos objetos de consumo na sociedade pós-moderna. Freud tratou o fetiche como objeto de desejo, substituto inapropriado do objeto sexual. A discussão de Leiris sobre as obras de Giacometti seguiram o mesmo parâmetro de Freud no sentido do fetiche como objeto de atração, desta vez, sentimental que os objetos de arte exercem sobre o indivíduo. No século $\mathrm{XX}$, essas aplicações do termo fetiche, externas ao contexto religioso, se consolidaram e vêm sendo empregadas conforme a situação. Em todo caso, o fetichismo é a adoração do objeto, o fetiche.

É evidente que esse caráter misterioso do fetiche, captado pelos autores ocidentais, decorre do fato de ser o fetiche, nas sociedades africanas, um objeto que transcende sua materialidade, por envolver desejos, crenças em poderes sobrenaturais, além de estruturas narrativas, chegando-se a crer que possui vida e alma.

Sociedades do Congo e de Angola possuem grande experiência na produção de amuletos usados para proteger os indivíduos contra os infortúnios, inclusive nos casos de doença. Os bakongo possuem especialistas em rituais (nganga) com amuletos, ervas, raízes, adivinhação e espíritos misteriosos, e duas figuras de funções opostas: o rei, a quem cabe zelar pelo bem comum, e o feiticeiro, que é a antítese deste bem comum. Noutras sociedades africanas da África Central e Ocidental, os infortúnios são atribuídos à bruxaria, 
que diverge da feitiçaria. A bruxaria, de uma parte, serve para explicar os infortúnios; de outra parte, é percebida como um regulador do comportamento social.

Concluímos que é preciso estudar, mas não devemos valorar a maneira de pensar das sociedades em que se pratica a bruxaria e a feitiçaria, tampouco enquadrá-las a modelos exteriores de religiosidade, porque não é uma manifestação isolada, é, pois, uma questão que envolve a história, as tradições, as estruturas e relações sociais previamente estabelecidas, o que pode ser demonstrado na invulnerabilidade de certos indivíduos, como os chefes políticos, que sempre são isentos de acusações de bruxaria ou de feitiçaria.

O tema em questão merece ser investigado em diversas sociedades, inclusive no Brasil, considerando-se as influências africanas, ibéricas e indígenas, além das especificidades dos lugares em que essas práticas são comuns. Essas investigações deverão aliar história, antropologia e sociologia, a fim de que se possa compreender a complexidade desses fenômenos.

\section{Referências}

1. CASCUDO, Luís da Câmara. Dicionário do folclore brasileiro. 2.ed. Rio de Janeiro: Instituto Nacional do Livro. Ministério da Educação e Cultura, 1991. 795 p.

2. DALGALARRONDO, Paulo. Civiliqação e loucura: uma introdução à história da etnopsiquiatria. São Paulo: Lemos, 1995. 124 p.

3. DE BROSSES, Charles. Du culte des dieux fetiches ou paralèle de l' antique religion de l' Egypte avec la religion actuelle de la negritie. Publicado s.n. Original da Oxford University, 1760. Digitalizado pela Oxford University, 29 jan. 2007. 285 p. Disponível em: <http://books.google.com/books?id=Sz8GAAAAQAAJ\&hl=ptBR> Acesso em: 20 jan. 2008.

4. DOUGLAS, Mary. Brujería: el estado actual de la questión. Trinta años depués de Brujéria, Oráculos y Magia entre os Azande. In: GLUCKMAN, Max et al. Ciência y de la brujería. Tradução Carlos Manzano. 3.ed. Barcelona: Editorial Anagrama, 1991, pp. 31-72.

5. DURKHEIM, Émile. As formas elementares da vida religiosa: o sistema totêmico na Austrália. Tradução Paulo Neves. São Paulo: Martins Fontes, 1996. 609 p.

6. EVANS-PRITCHARD, Edward Evan. Antropologia Social. Lisboa: Edições 70, 1972. $210 \mathrm{p}$.

7. B Bruxaria, oráculos e magia entre os Azande. Tradução Eduardo Viveiros de Castro. Rio de Janeiro: Jorge Zahar, 1978. 316 p.

8. FRAZER, James George. La rama dorada: magia y religion. 3.ed. Mexico; Buenos Aires: Fondo de Cultura Econômica, 1956. 860 p.

9. FONTENELLE, Isleide Arruda. O trabalho da ilusão: produção, consumo e subjetividade na sociedade contemporânea. Interações, v.10, n. 19, pp. 63-86, 2005.

10. FREUD, Sigmund. Totem y tabu. Algunos aspestos comunes entre la vida mental del hombre primitivo y los neuroticos. In: .Obras completas de Freud. Tomo II. 4.ed. Biblioteca Nueva, 1981a, pp.1745-1850.

11. . Tres ensayos para uma teoria sexual. In: - Obras completas de Freud. Tomo II. 4.ed. Biblioteca Nueva, 1981b, pp.1172-94. 
12. GESCHIERE, Peter. Feitiçaria e modernidade nos Camarões: alguns pensamentos sobre uma estranha cumplicidade. Afro-Ásia, n. 34, pp. 9-38, 2006.

13. GLUCKMAN, Max. La Lógica de la Ciência y de la brujería africanas. In: GLUCKMAN, Max et al. Ciência y de la brijería. Tradução Carlos Manzano. 3.ed. Barcelona: Editorial Anagrama, 1991. p. 7-30.

14. MARX, Karl. O Capital: crítica da economia política. Livro I. Tradução Reginaldo Sant'Anna. 24.ed. Rio de Janeiro: Civilização Brasileira, 2006. 571 p.

15. PARÉS, Luis Nicolau. A formação do candomblé: história e ritual da nação jeje na Bahia. Campinas: Editora da Unicamp, 2006. 390 p.

16. PIETZ, William. The problem of the fetish, I. Res: Anthropology and Aesthetics, n. 9, pp. 5-17, 1985.

17. The problem of the fetish, II. The Origin of the Fetish. Res: Anthropology and Aesthetics, n. 13, pp. 23-45, 1987.

18. The problem of the fetish, IIIa: Bosman's Guinea and the Enlightenment Theory of Fetichism. Res: Anthropology and Aesthetics, n. 16, pp. 106-123, 1988.

19. THOMPSON, Robert Farris. The two sign of the four moments of the sun: Kongo and religion art in the Americas. In: Flash of the spirit. Africain \& AfroAmericain Art \& Pilhosophy. New York; Toronto: First Vintage Books Edition, 1984. pp. 103-158.

\section{Agradecimentos}

Ao Prof. Dr. Luis Nicolau Parés, do Centro de Estudos Afro-Orientais da Universidade Federal da Bahia, por sua orientação e por ter disponibilizado os textos fundamentais para a elaboração deste artigo;

À historiadora Simone Rubim de Pinho Lima, pelas discussões durante a revisão do texto. 